연구노트

\title{
Quality changes in mushroom (Agaricus bisporus) due to storage temperature and packing film
}

\author{
Ji-Hyun Lee*, Ji-Weon Choi, Eun-Ha Chang, Il Sheob Shin, Yoon-Pyo Hong \\ Postharvest Technology Division, National Institute of Horticultural and Herbal Science, Wanju 55365, Korea
}

\section{포장 필름과 저장 온도 조건에 따른 양송이버섯의 품질 변화}

\author{
이지현*·최지원 · 장은하·신일섭·홍윤표 \\ 국립원예특작과학원 저장유통과
}

\begin{abstract}
This study was conducted to investigate the effects of temperature and packing film with varying oxygen transmission rate (OTR) on the quality of Agaricus bisporus (mushrooms) to determine the optimum modified atmosphere package. Mushrooms were packed using $10 \mu \mathrm{m}$ polyvinyl chloride (PVC), and $30 \mu \mathrm{m}$ oriented polypropylene (OPP) films with the OTR ranging from 1,000 to $20,000 \mathrm{~mL} / \mathrm{m}^{2} / \mathrm{day} / \mathrm{atm}(\mathrm{OPP} 1000$, OPP6000, OPP10000, and OPP20000). The quality parameters including weight loss, gas composition, cap opening rate, stipe elongation, firmness, and color of mushrooms were monitored at the following temperatures: $4^{\circ} \mathrm{C}, 8^{\circ} \mathrm{C}, 12^{\circ} \mathrm{C}$, and $20^{\circ} \mathrm{C}$. Overall, the mushrooms packed in OPP films showed less change in weight loss, cap opening rate, stipe elongation, and firmness than those of the control, however, these effects differed with the temperature and film OTR. Among the OPP films, OPP20000 did not exhibit any effect with respect to tissue growth inhibition. OPP1000 and OPP6000 were the most effective in suppressing the cap opening rate and stipe elongation but induced tissue damage and water soaking in the internal section. In contrast, the mushrooms packed in PVC film showed less change in weight loss, cap opening rate, and stipe elongation than those of the control, and browning of inside and outside of mushroom was less than that mushroom packed in OPP film.
\end{abstract}

Key words : Agricus bisporus, modified atmosphere packing, oxygen transmission rate, quality

\section{서 론}

양송이(Agaricus bisporus)는 영양소가 풍부하고 맛과 향 기가 뛰어나 세계적으로 가장 널리 소비되는 버섯 중 하나 로 최근 국내에서는 건강에 대한 관심과 서양음식의 대중화 로 소비가 증가하는 추세이다(1). 국산 양송이의 유통은 농가에서 수확 직후 저장고에서 예냉을 실시한 뒤 expanded polystyrene(EPS)나 골판지 종이상자에 $2 \mathrm{~kg}$ 씩 담아 이루어 지고 최종 소비지에서 소형용기 및 필름포장으로 소포장되

*Corresponding author. E-mail : leejh80@korea.kr Phone : 82-63-238-6531, Fax : 82-63-238-6505

Received 21 June 2018; Revised 23 August 2018; Accepted 1 October 2018.

Copyright (c) The Korean Society of Food Preservation. All rights reserved.
어 판매된다(2). 그러나 양송이는 호흡이 왕성하고 표피에 큐티클(cuticle)층이 없이 얇아 물리적 충격에 약하고 수분 손실이 높으므로 유통 중 품질저하가 빠르게 나타난다(3, 4). 따라서 관행적인 유통방법은 겨울에 3-4일, 여름에 2 일 이내에 상품가치가 떨어져 유통 중 손실률이 높은 것이 문제가 된다(5).

양송이의 품질을 유지하기 위한 방법으로 예냉처리(6,7), $\mathrm{UV}$ 조사(8), 코팅제 처리(5,9), methyl jasmonate(MJ) 침지 처리(10), 이산화염소 훈증(11) 및 modified atmosphere(MA) 포장(12-14) 등이 연구되었다. 그 중 $\mathrm{MA}$ 포장은 현장 적용 이 가장 간편하고 효과가 높아 경제적인 수확후관리 기술 중 하나이다. $\mathrm{MA}$ 포장 필름 내부에 작물의 호흡으로 인해 조절된 기체조성은 대기보다 이산화탄소가 높고 산소가 낮으며, 이러한 환경은 호흡률과 에틸렌 발생량 및 민감도 를 낮추고 작물의 생리적 변화와 부패를 감소시킨다 
(15-17). 그러나 과도한 이산화탄소의 축적 혹은 산소의 결 핍은 버섯에서 세포막 손상과 갈변, 경도 감소, 이취 발생과 같은 생리적 장해를 야기할 수 있어 $(18,19)$ 작물의 특성과 유통환경에 적합한 $\mathrm{MA}$ 포장 기술을 연구할 필요가 있다.

MA 포장에서 주로 이용되는 필름은 polyethylene(PE), polypropylene(PP), polystyrene(PS)와 polyvinyl chloride(PVC) 이며 각 필름이 가진 투기성(permeability)과 투습성(water vapor transmission rate)은 작물의 호흡률에 따라 다양한 기체조성과 습도 환경을 형성하게 되고 이는 작물의 품질에 결정적인 영향을 미친다. 양송이의 $\mathrm{MA}$ 연구는 오랜기간 이루어졌으나 controlled atmosphere(CA) 저장을 위한 최적 가스조성에 대해서는 발표된 것이 거의 없다(20). 따라서 본 연구에서는 양송이에 적합한 $\mathrm{MA}$ 필름 개발에 앞서 주로 이용되는 PVC 필름과 산소투과도를 조정한 oriented polypropylene(OPP) 필름을 이용하여 다양한 유통온도에서 양송이의 품질변화를 조사하고 필름 내부에 형성되는 기체 조성과 유통온도가 양송이 품질에 미치는 영향을 분석하고 자 하였다.

\section{재료 및 방법}

\section{시험재료}

양송이버섯은 2017년 7월 충남 부여군 소재의 재배농장 에서 수확한 새도 품종 중 중량 23-25 g의 균일한 샘플을 선별하여 이용하였다. 버섯은 수확 당일 관행적으로 이용 되는 EPS $2 \mathrm{~kg}$ 규격 박스에 담아 품온이 $5^{\circ} \mathrm{C}$ 가 되도록 예냉 을 실시한 뒤 전주소재의 실험실로 옮겨와 실험에 사용하였다.

\section{시험처리 및 저장}

버섯 시료는 통기구가 있는 polyethylene terephthalate(PET) 소재의 용기 $(150 \mathrm{~L} \times 110 \mathrm{~W} \times 35 \mathrm{H} \mathrm{mm})$ 에 6 개씩 담아 140-150 g으로 준비하였다. MA 포장처리는 PET 용기를 필름으로 씨워서 접착기로 밀봉하는 방식으로 실시하였고 이용된 필름은 $30 \mu \mathrm{m} \mathrm{OPP} \mathrm{필름에} \mathrm{산소투과도(oxygen}$ transmission rate, OTR)를 조절하여 $1,000,6,000,10,000$, $20,000 \mathrm{~mL} / \mathrm{m}^{2} / \mathrm{day} / \mathrm{atm}$ 로 준비한 4종과 $10 \mu \mathrm{m}$ PVC 스트레 칭 랩을 이용하였다. 또한 필름을 처리하지 않은 대조구를 추가하였다. 포장처리가 끝난 뒤 온도 $4,8,12,20^{\circ} \mathrm{C}$ 의 저장 고에 보관하며 이화학적 품질을 분석하였다.

\section{필름 내부 기체조성 측정}

필름 포장 내부의 기체조성은 $\mathrm{O}_{2} / \mathrm{CO}_{2}$ analyzer(CheckMate III, PBI Dansensor, Ringsted, Denmark)를 이용하여 기기에 연결된 주사바늘을 저장 중인 양송이버섯의 포장 내부에 직접 삽입하여 head space 기체를 측정하였다.

\section{이화학적 품질 분석}

중량감소율은 포장 직후 중량을 측정하여 초기 중량으로 하고 유통 중 손실된 중량을 초기 중량과 대비하여 백분율 로 환산하였다. 버섯의 경도는 양송이 갓 중앙부위를 측정 하였고 texture analyzer(TA ST2, Lloyd Instruments, Hampshire, UK)를 이용하여 직경 $5 \mathrm{~mm}$ 의 probe가 $3 \mathrm{~mm} / \mathrm{s}$ 의 속도로 $8 \mathrm{~mm}$ 의 깊이까지 뜷고 들어갈 때의 힘을 $\operatorname{Newton}(\mathrm{N})$ 값으로 나타내었다. 색도는 버섯의 외부와 내부 로 나누어 측정하였는데 외부는 양송이 갓 중앙부위를, 내 부는 양송이를 종단면으로 절단하여 절단면의 중앙부위를 측정하였으며 표준백판 $\left(\mathrm{L}^{*}=97.75, \mathrm{a}^{*}=-0.43, \mathrm{~b}^{*}=0.29\right)$ 으로 보정된 색차계(CR-400, Minolta, Osaka, Japan)을 이용하여 $\mathrm{CIE} \mathrm{L}$ (명도) 값과 $\mathrm{b}^{*}$ (황청도) 값을 측정하였다. 갓 개열율 은 갓이 베일이 열리면서 양송이 대에서 분리된 부분이 $50 \%$ 를 넘는 개체의 수를 총 샘플 수에 대비하여 백분율로 환산하였다. 대 길이 생장은 포장 전 초기 대의 길이와 측정 부위를 표시해두고 유통기간에 따라 생장한 대의 길이를 측정하여 조사하였다.

\section{통계분석}

필름 내 공기조성, 중량감소율, 갓개열율은 3 반복, 대 길이생장은 4 반복, 경도 및 색도는 8 반복으로 각각 분석하 여 평균값으로 나타내었고 실험결과의 통계처리는 SAS system(ver 9.2, SAS Institute Inc., Cary, NC, USA)을 사용하 여 분산분석(ANOVA)을 하였다. 처리 간 유의차 검증은 Duncan's multiple range test(DMRT)로 5\% 수준에서 검증하 였다.

\section{결과 및 고찰}

\section{중량감소율}

양송이의 저장 온도별 포장 필름에 따른 중량감소 변화 는 Fig. 1 과 같다. 필름 포장을 하지 않은 대조구의 경우 저장기간 6 일을 기준으로 하였을 때 $4,8,12^{\circ} \mathrm{C}$ 에서 양송이 의 중량이 각각 $4.2,4.2,4.8 \%$ 감소하였고 $20^{\circ} \mathrm{C}$ 에서는 저장 3 일 만에 $7.8 \%$ 까지 감소하였다. 반면 $\mathrm{PVC}$ 필름 처리구는 저장기간 6 일에 $4,8,12^{\circ} \mathrm{C}$ 에서 각각 $1.6,2.1,3.4 \%, 20^{\circ} \mathrm{C}$ 에서 는 저장 3 일에 $3.2 \%$ 의 중량이 감소하여 대조구에 비해 29.2-61.9\% 수준 중량감소가 억제되었다. OPP 필름을 이용 한 포장 처리구는 같은 기간을 기준으로 했을 때 0.0-0.4\% 수준으로 감소하였고 대조구와 PVC 처리구에 비해 모든 온도에서 유의적으로 $(\mathrm{p}<0.05)$ 낮은 값을 나타내었다. 버섯 은 표피의 막이 앏고 다공성 구조로 되어있어 빠른 증산현 상을 막을 수 없다(21)고 하였는데 필름처리를 하지 않은 대조구의 경우 $4^{\circ} \mathrm{C}$ 의 낮은 온도와 $83.3 \pm 5.3 \%$ 의 다소 높은 상대습도 환경 하에서도 12 일 경과 후 $9.1 \%$ 의 높은 중량감 

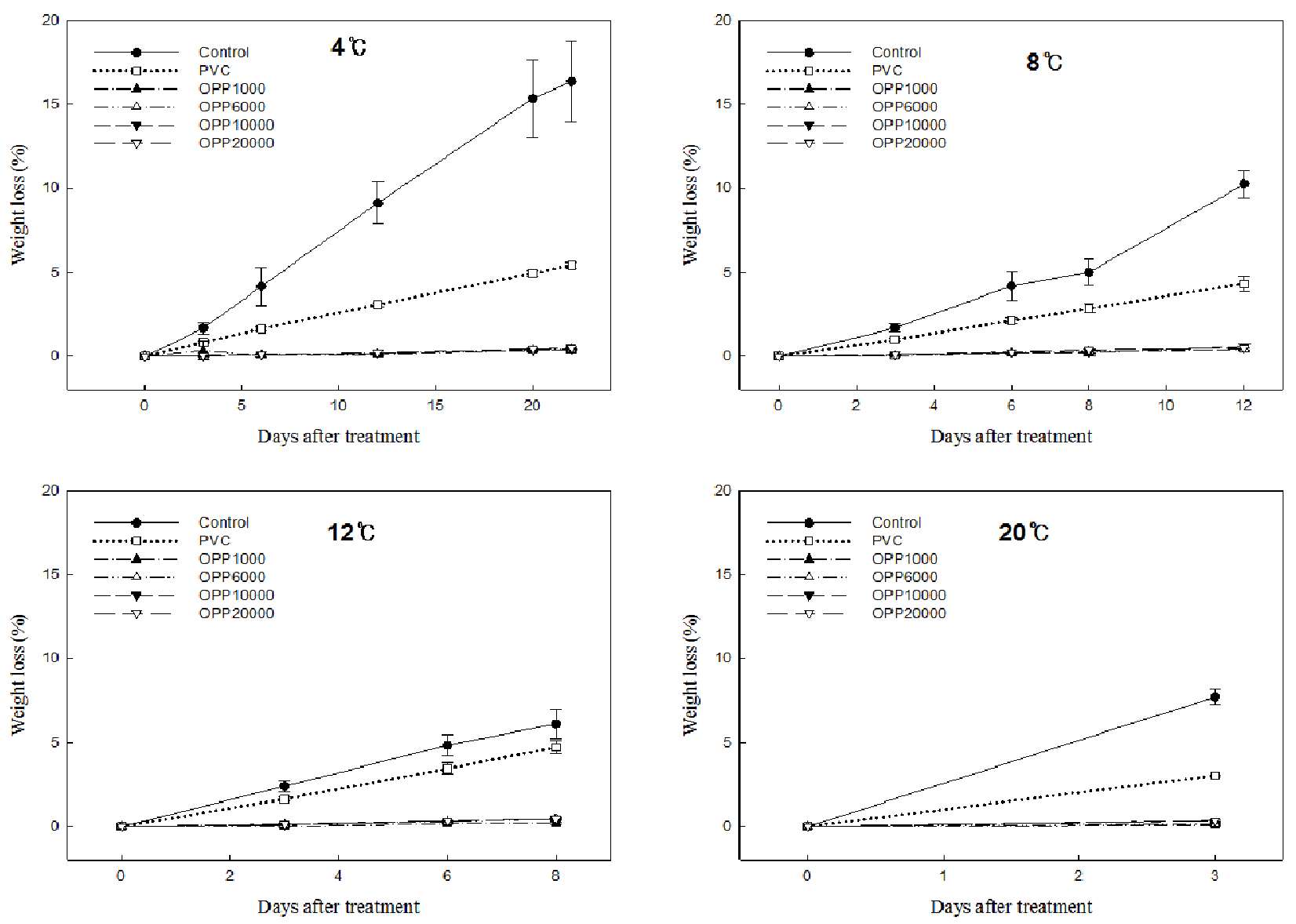

Fig. 1. Changes in weight loss of button mushroom with different packaging film during storage at $4,8,12,20^{\circ} \mathrm{C}$.

Values are means $\pm \mathrm{SD}(\mathrm{n}=3)$.

소가 나타났다. OPP와 $\mathrm{PVC}$ 필름을 비교하였을 때, $\mathrm{OPP}$ 필름이 산소투과도에 관계없이 $\mathrm{PVC}$ 필름보다 유의하게 낮은 중량감소가 나타났는데, Lee 등(22)의 실험에서 $10^{\circ} \mathrm{C} 17$ 일 경과 시 PP 필름 포장된 양송이의 중량감소가 $1.03 \%$ 로 $\mathrm{PVC}$ 처리구(7.73\%)에 비해 현저히 낮은 것과 유사한 결과 였다. PVC 필름의 투습도는 $15-40 \mathrm{~g} / \mathrm{m}^{2} / \mathrm{day}$ 으로 PP 필름의 4-11 g에 비해 높은 특성이 있으며(20) 이러한 차이가 저장 중 중량감소에 반영된 것으로 판단된다.

\section{포장 내 가스 조성 변화}

원예작물의 $\mathrm{MA}$ 포장은 필름의 종류와 작물의 호흡량에 따라 포장 내부의 가스 농도가 다르게 조성되며 이때 평형 을 이루는 산소 및 이산화탄소의 농도는 작물의 품질에 영향을 미친다 $(17,20)$. 본 실험에서는 필름 종류와 저장 온 도에 따라 다양하게 조성되는 가스 농도를 분석하고 각각의 가스 조성이 양송이 품질에 미치는 영향을 분석하고자 하였 다. 양송이 $\mathrm{MA}$ 포장 필름 종류 및 저장 온도에 따른 필름 내 산소 농도 변화는 Fig. 2 와 같으며 각 필름에 따른 내부 산소 농도는 저장 온도별로 양상이 다르게 나타났다. $4^{\circ} \mathrm{C}$
저장에서는 PVC 필름의 산소 농도가 11.2-16.1\%로 저장 6 일까지 대조구보다 유의적으로 $(\mathrm{p}<0.05)$ 낮은 산소 농도를 유지하였다. OPP 1000 은 OPP 필름 중 산소 농도가 낮은 경향이었으나 통계처리 결과 유의적인 $(\mathrm{p}<0.05)$ 차이는 없 었고 대조구와 유사한 농도를 나타냈다. $8^{\circ} \mathrm{C}$ 저장에서 내부 산소 농도를 분석한 결과 저장기간 동안 PVC는 6.4-13.4\%, OPP 1000 은 9.2-14.5\%로 서로 유사한 농도를 보였고 대조 구보다는 유의하게 낮았다. OPP6000, OPP 10000 , OPP20000은 각각 $13.5-15.7 \%, 13.9-19.0 \%, 16.7-18.5 \%$ 의 범위에 있었으며 대조구(20.9\%)보다 산소 농도가 낮은 경 향을 보였으나 저장기간이 경과함에 따라 대조구와 유의한 차이를 나타내지 않았다. $12^{\circ} \mathrm{C}$ 저장에서는 저장 초기부터 각 처리구별로 유의한 산소 농도의 차이를 나타냈으며 모든 처리구가 대조구보다 낮은 값을 보였다. OPP 1000 , $\mathrm{OPP} 6000, \mathrm{OPP} 10000, \mathrm{OPP} 20000$ 은 각각 $0.1-5.3 \%$, $3.7-8.3 \%, 8.0-12.7 \%, 14.1-17.0 \%$ 로 산소투과도가 높을수록 유의하게 낮은 농도에서 평형을 이루었고 $\mathrm{PVC}$ 는 저장 1 일 차에 $0.6 \%$ 로 가장 낮은 농도였다가 저장기간이 경과함에 따라 점차 증가하여 $12.4 \%$ 를 나타내었다. $20^{\circ} \mathrm{C}$ 저장에서는 

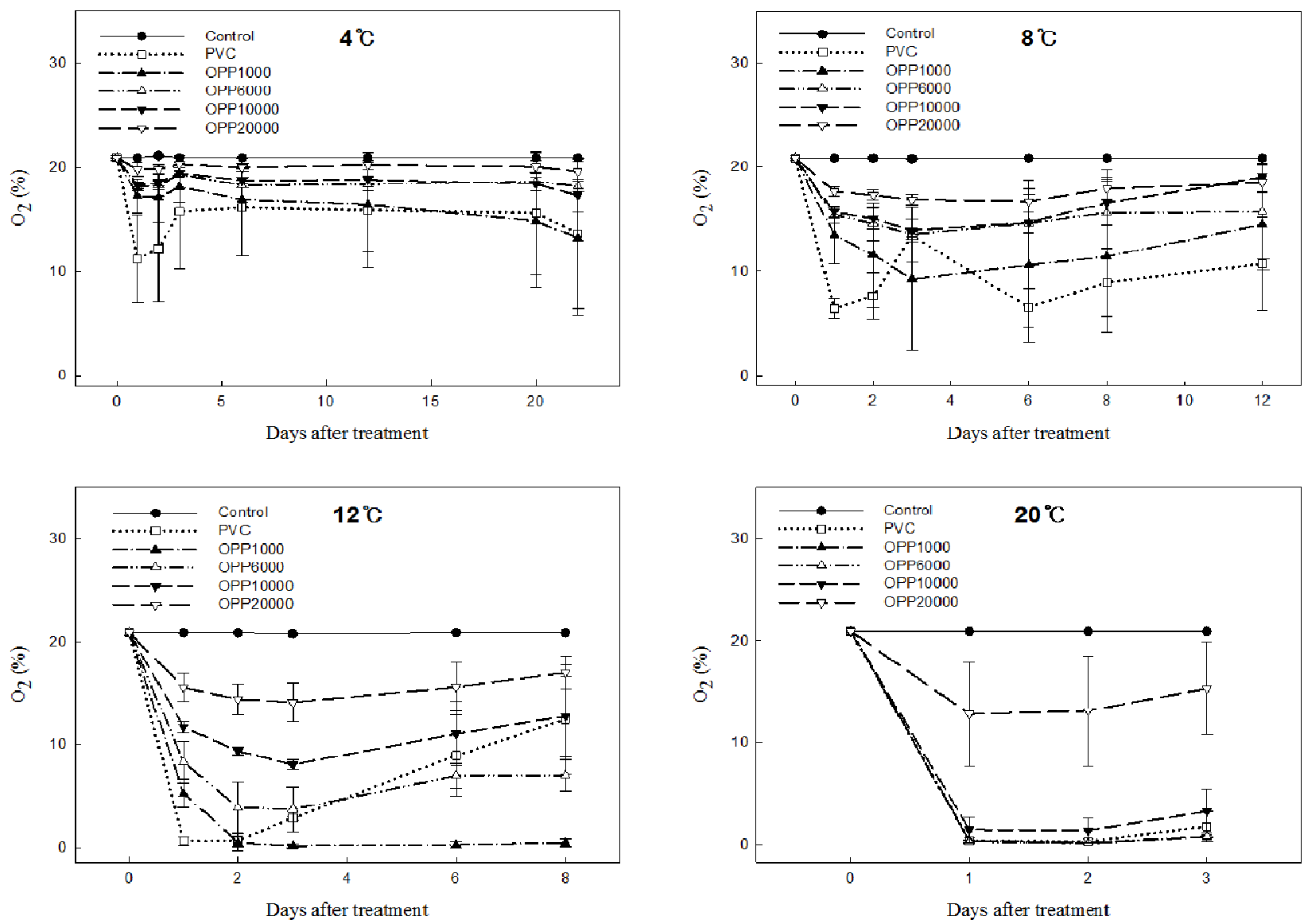

Fig. 2. Changes in $\mathrm{O}_{2}$ concentration within package of button mushroom with different packaging film during storage at $4,8,12,20^{\circ} \mathrm{C}$. Values are means $\pm \mathrm{SD}(\mathrm{n}=3)$.

PVC, OPP1000, OPP6000, OPP10000 처리구가 산소 농도 $0.1-3.2 \%$ 를 나타내며 서로 유사하였고 OPP20000이 12.8-15.3\%로 유의하게 높은 값을 나타내었다.

한편 4 와 $8^{\circ} \mathrm{C}$ 저장에서 $\mathrm{PVC}$ 처리구의 필름 내 산소농도 가 1 일 차에 급격히 감소했다가 이후 3 일까지 증가하고 이후 평형을 이루었는데 이는 양송이 포장 당시 $22 \pm 2.0^{\circ} \mathrm{C}$ 의 환경에서 포장하고 이를 4 와 $8^{\circ} \mathrm{C}$ 저장고에 넣었던 바 초기 에 높은 품온에 의해 호흡량이 높아 필름 내부의 산소 농도 가 급격히 낮아졌고 PVC 필름의 산소투과성이 낮아 평형을 이루는데 시간이 소요된 것으로 생각되고 이후 낮은 온도에 서 호흡량이 감소하며 보다 높은 수준에서 평형을 이룬 것으로 판단된다. $\mathrm{OPP}$ 필름의 경우에도 $4^{\circ} \mathrm{C}$ 에서 산소투과 도가 낮을수록 $\mathrm{PVC}$ 와 유사한 경향을 보였으나 $\mathrm{PVC}$ 에 비해 빠르게 평형을 이루었다. $\mathrm{OPP}$ 와 $\mathrm{PVC}$ 를 비교하였을 때 낮 은 온도에서 $\mathrm{PVC}$ 의 산소 투과 속도가 더욱 낮은 특성을 가졌을 것으로 예상되며 필름의 온도별 특성에 대해서 좀 더 깊은 검토가 요구된다.

각 필름에 따른 내부 이산화탄소 농도는 저장 온도별로 양상이 다르게 나타났다(Fig. 3 ). $4^{\circ} \mathrm{C}$ 저장에서는 OPP1000
이 저장 22 일 동안 2.6-6.8\%로 농도가 가장 높은 경향이었으 나 PVC, OPP6000, OPP10000 처리구와는 유의적인 $(\mathrm{p}<0.05)$ 차이가 없었다. OPP20000은 0.8-1.5\% 수준으로 필름 처리구 중 가장 낮은 이산화탄소 농도를 나타내었다. $8^{\circ} \mathrm{C}$ 저장의 이산화탄소 농도를 분석한 결과 $\mathrm{OPP} 1000$, $\mathrm{OPP} 6000, \mathrm{OPP} 10000$ 은 저장 12 일 동안 각각 6.1-9.9\%, 5.1-7.2\%, 2.3-7.1\%로 대조구보다 높았으나 서로 유의적인 $(\mathrm{p}<0.05)$ 차이를 나타내지 않았다. PVC는 이산화탄소 농도 2.7-5.1\%로 OPP20000(2.6-4.3\%)과 서로 유사하였다. $12^{\circ} \mathrm{C}$ 저장에서는 $\mathrm{OPP} 1000$ 과 $\mathrm{OPP} 6000$ 이 각각 저장 8 일 동안 $12.1-17.0 \%, 10.7-16.6 \%$ 로 다른 처리구에 비해 유의하게 높았고 다음으로 $\mathrm{OPP} 10000$ 이 8.1-13.1\%로 높았으며 OPP20000과 PVC가 각각 3.9-7.4\%, 3.3-6.6\%로 대조구보다 높은 농도를 유지하였고 서로 유사하였다. $20^{\circ} \mathrm{C}$ 저장에서 는 $\mathrm{OPP} 1000, \mathrm{OPP} 6000, \mathrm{OPP} 10000$ 이 저장 3 일 동안 이산화 탄소 농도 14.0-18.9\%를 나타내며 가장 높은 농도로 평형을 이루었고 다음으로 OPP20000과 PVC가 2.7-8.1\%의 범위로 서로 유사하였다.

포장 내 가스 농도 결과를 종합하여 볼 때, OPP 필름의 

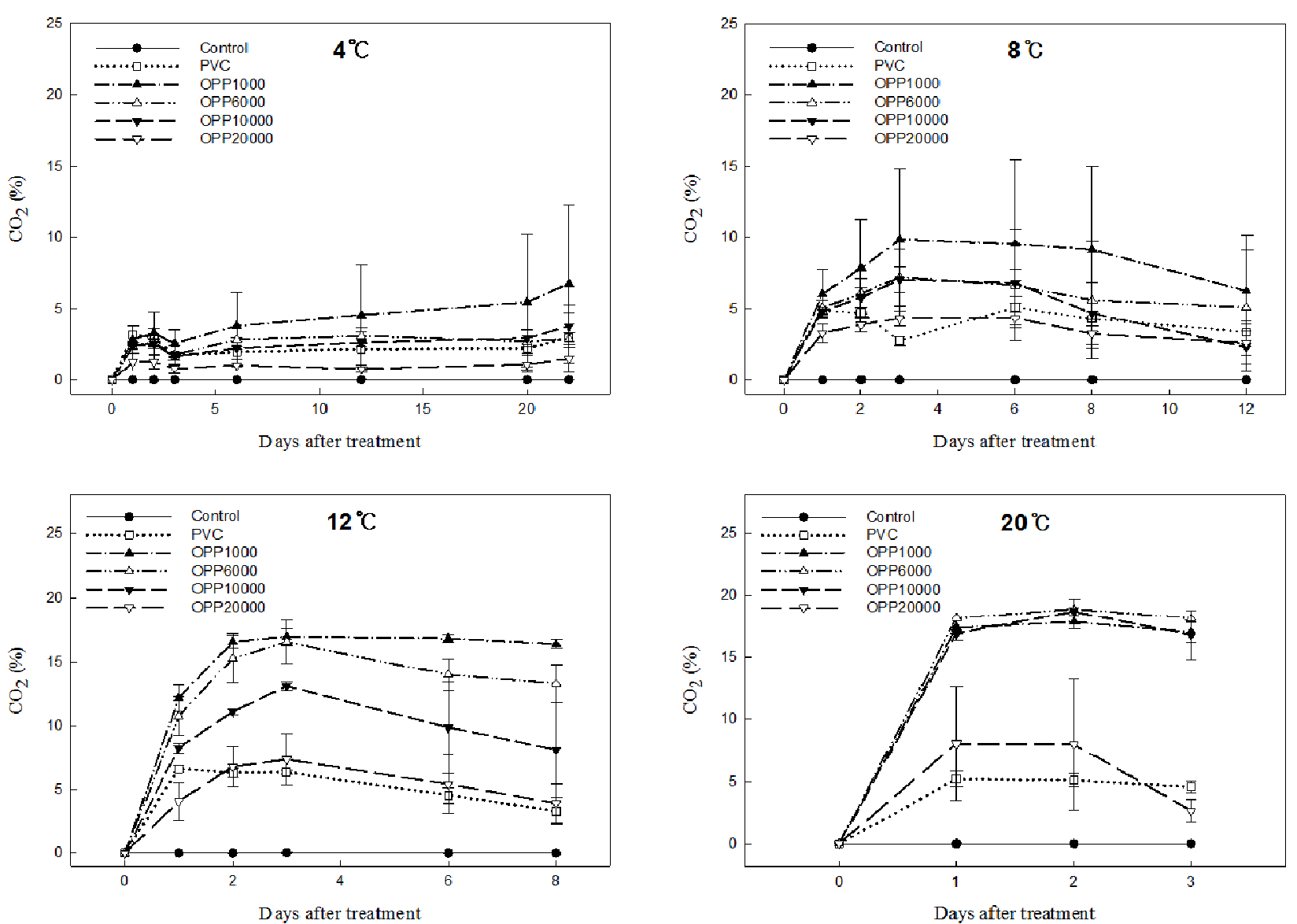

Fig. 3. Changes in $\mathrm{CO}_{2}$ concentration within package of button mushroom with different packaging film during storage at $4,8,12,20^{\circ} \mathrm{C}$. Values are means $\pm \mathrm{SD}(\mathrm{n}=3)$.

OTR이 낮을수록 필름 내부의 산소 농도는 낮고 이산화탄 소 농도는 높은 경향이었다. 그러나 저장 온도가 낮아서 호흡량이 적을 때나 반대로 저장 온도가 높아 호흡량이 많을 때는 필름 OTR에 따른 필름 내부 가스 농도 차이가 크지 않았다. 한편 $\mathrm{PVC}$ 필름은 전반적으로 산소의 농도는 OPP 1000 과 가장 유사하였으나 이산화탄소의 농도는 OPP20000과 가장 유사하여 두 기체의 투과에 있어서 다른 경향이 나타났다.

\section{갓 개열율}

저장 온도별 $\mathrm{MA}$ 포장에 따른 양송이 품질 변화를 분석하 였다. 양송이 품질저하의 주요 원인으로는 갓 개열, 대 신장, 포자 형성, 표면색택 및 조직감 변화 등이며 $(23,24)$ 따라서 품질을 평가함에 있어 갓의 상태와 표면의 변색정도, 조직 의 견고도 변화는 품질 평가에 중요한 지표가 된다. 저장 온도 및 필름 종류별 양송이 갓 개열율 변화는 Fig. 4에 나타내었다. 필름포장을 하지 않은 대조구에서는 $8,12,20^{\circ} \mathrm{C}$ 저장에서 각각 $6,3,1$ 일에 갓 개열율이 $50 \%$ 를 넘었고 8 , 6,2 일에 $90 \%$ 이상의 양송이 갓이 개열되었다. $8^{\circ} \mathrm{C}$ 저장에
서는 모든 필름 처리구에서 대조구보다 갓 개열이 억제되었 고 필름 처리 간의 유의적인 $(\mathrm{p}<0.05)$ 차이는 없었다. $12^{\circ} \mathrm{C}$ 저장에서는 저장 8 일 차에 $\mathrm{OPP} 1000, \mathrm{OPP} 6000$ 이 각각 5.6과 $11.1 \%$ 로 가장 낮았고 $\mathrm{PVC}$ 의 갓 개열율이 $50.0 \%$ 로 대조구 보다 낮았으나 필름 처리구 중에서는 가장 높은 경향이었 다. $20^{\circ} \mathrm{C}$ 저장에서는 필름 처리구 중 $\mathrm{PVC}, \mathrm{OPP} 1000$, $\mathrm{OPP} 6000, \mathrm{OPP} 10000$ 이 저장 3 일 차에 11.1-27.8\%로 낮은 갓 개열율을 나타내었고 OPP20000은 $77.8 \%$ 로 대조구와 차이가 없었으며 갓 개열을 억제하지 못하였다. 한편, $4^{\circ} \mathrm{C}$ 저장에서는 대조구를 비롯한 모든 필름 처리구에서 저장 22 일까지 갓 개열이 나타나지 않았다.

본 실험에서 내부 가스조성과 갓 개열율의 관계를 분석 하였을 때, $4^{\circ} \mathrm{C}$ 에서는 모든 처리구에서 갓 개열이 거의 없고 온도가 높아질수록 일부 필름에서 갓 개열율이 증가하는 것으로 보아 온도가 가장 중요한 요인이고, 같은 온도 내에 서는 가스조성이 영향을 미치는 것으로 판단된다. 각 온도 에서 갓 개열율이 $30 \%$ 이하인 처리구의 가스조성을 분석한 결과, $20^{\circ} \mathrm{C}$ 에서는 $\mathrm{O}_{2} 2 \%$ 수준 이하 $\mathrm{CO}_{2} 15 \%$ 수준 이상, $12^{\circ} \mathrm{C}$ 에서는 $\mathrm{O}_{2} 10 \%$ 이하 $\mathrm{CO}_{2} 10 \%$ 이상, $8^{\circ} \mathrm{C}$ 는 $\mathrm{O}_{2} 18 \%$ 이하 

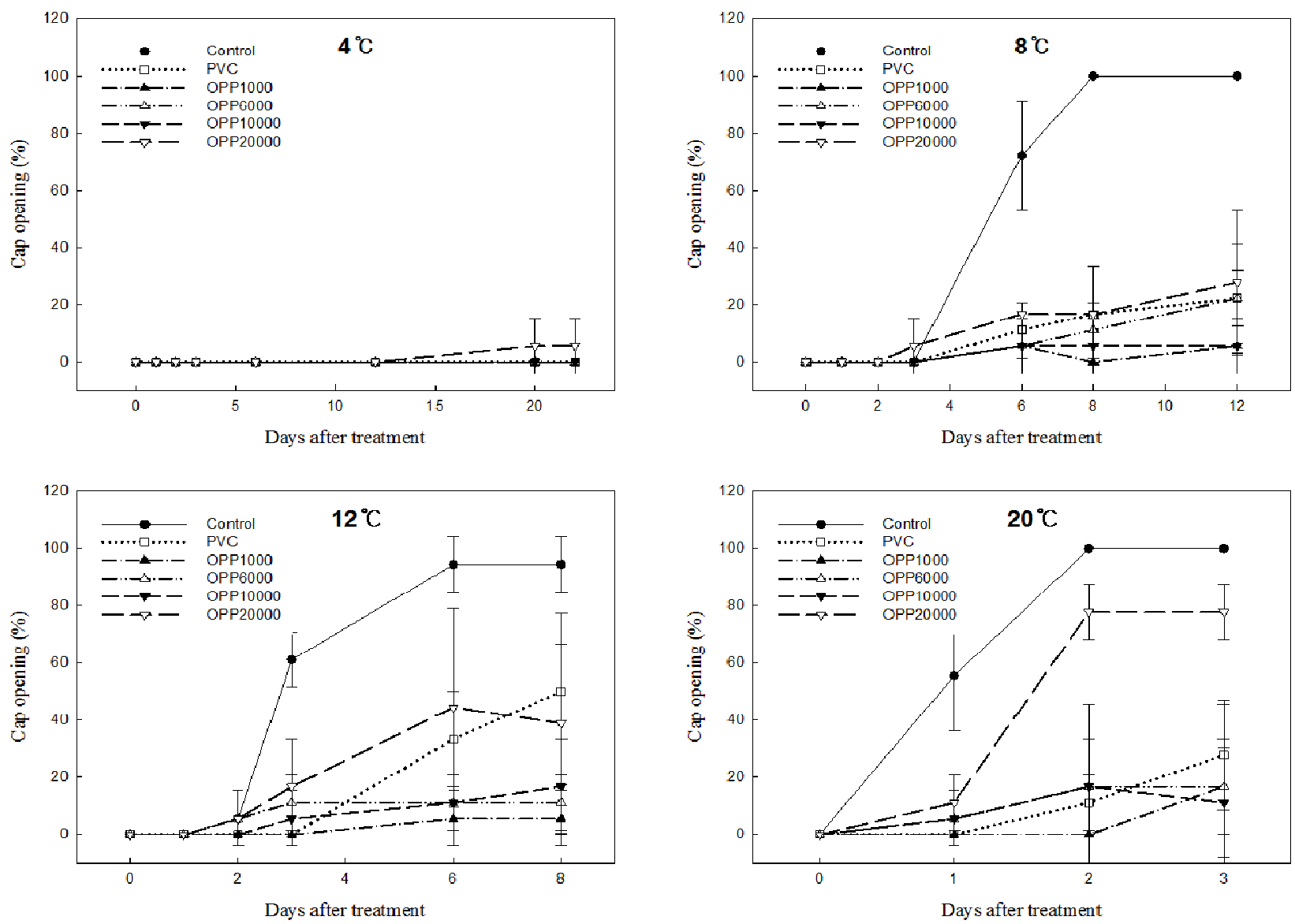

Fig. 4. Changes in cap opening ratio of button mushroom with different packaging film during storage at $4,8,12,20^{\circ} \mathrm{C}$.

Values are means \pm SD $(n=3)$.

$\mathrm{CO}_{2} 3 \%$ 이상이었다. Sveine 등(25)은 갓 개열의 억제에 최적 가스 조성은 $\mathrm{O}_{2} 0.1 \%$ 와 $\mathrm{CO}_{2} 5 \%$ 라 보고하였고, Murr와 Morris(26)는 0\% $\mathrm{O}_{2}$ 는 갓 생장을 지연, $5 \% \mathrm{O}_{2}$ 는 촉진시킨다 고 하였으며 Nichols과 Hammond(27)는 $18^{\circ} \mathrm{C}$ 에서 $1-2 \% \mathrm{O}_{2}$, $10-12 \% \mathrm{CO}_{2}$ 환경 하에서 갓 생장이 지연된다고 하여 농도 는 조금씩 달랐으나 낮은 $\mathrm{O}_{2}$ 와 높은 $\mathrm{CO}_{2}$ 환경에서 억제된 다고 보고되었다. 본 실험 분석 결과 또한 낮은 $\mathrm{O}_{2}$ 와 높은 $\mathrm{CO}_{2}$ 환경에서 갓 개열이 억제되었으나 가스 농도는 온도가 높을수록 산소 농도가 낮고 이산화탄소 농도가 높은 수준에 서 억제되어 온도에 따라 갓 개열 억제에 최적인 가스 농도 는 차이가 있는 것으로 판단된다.

\section{대 신장}

대 신장 변화는 Fig. 5에 나타내었다. 저장 기간이 경과함 에 따라 양송이 대가 신장하였으며 $4^{\circ} \mathrm{C}$ 저장에서는 갓 개열 과 마찬가지로 모든 처리구에서 대 신장이 $3 \mathrm{~mm}$ 내외로 생장이 억제되었고 처리간 차이가 없었다. 처리구별 저장 후기 대 신장 값을 비교하였을 때, $4^{\circ} \mathrm{C}$ 를 제외하고는 전반적 으로 OPP20000 > 대조구 $\geq$ PVC, OPP6000, OPP10000
$>\mathrm{OPP} 1000$ 의 순으로 값이 낮아졌고 통계처리 결과 유의한 차이를 나타내었다 $(\mathrm{p}<0.05)$.

필름 처리구는 필름 종류에 따라 대 생장이 대조구와 유사하거나 억제 혹은 촉진되는 결과를 나타내었다. 내부 가스 조성과 대 신장과의 관계를 분석하였을 때, 전반적으 로 산소 농도가 낮고 이산화탄소가 높을수록 대 신장이 억제되는 경향이었다. 그러나 OPP20000은 산소 농도가 8, $12,20^{\circ} \mathrm{C}$ 에서 각각의 저장 기간 $12,8,3$ 일 동안 평균 17.5 , $15.3,13.7 \%$ 였고, 이산화탄소 농도는 각각 $3.4,5.5,6.2 \%$ 으 로 대조구에 비해 산소는 낮고 이산화탄소는 높았으나 오히 려 대 신장이 더욱 촉진되었다. 이는 대의 생장을 억제하는 가스 농도 범위를 벗어나면 다음은 습도가 대의 생장 속도 에 영향을 미치는 것으로 판단된다. 습도가 양송이에 미치 는 영향을 분석하기 위한 예비실험에서 가스농도를 대기와 같이 조정하고 상대습도만 55-65\%와 90- $100 \%$ 로 조절하여 처리하였을 때, 갓 개열은 차이가 없었으나 높은 습도 처리 구에서 대 신장의 값이 현저히 높은 수치를 나타낸 것과 같은 결과였다(data not shown). 따라서 양송이 대 신장은 온도, 습도 및 가스 농도가 영향을 미치는 것으로 생각되고 

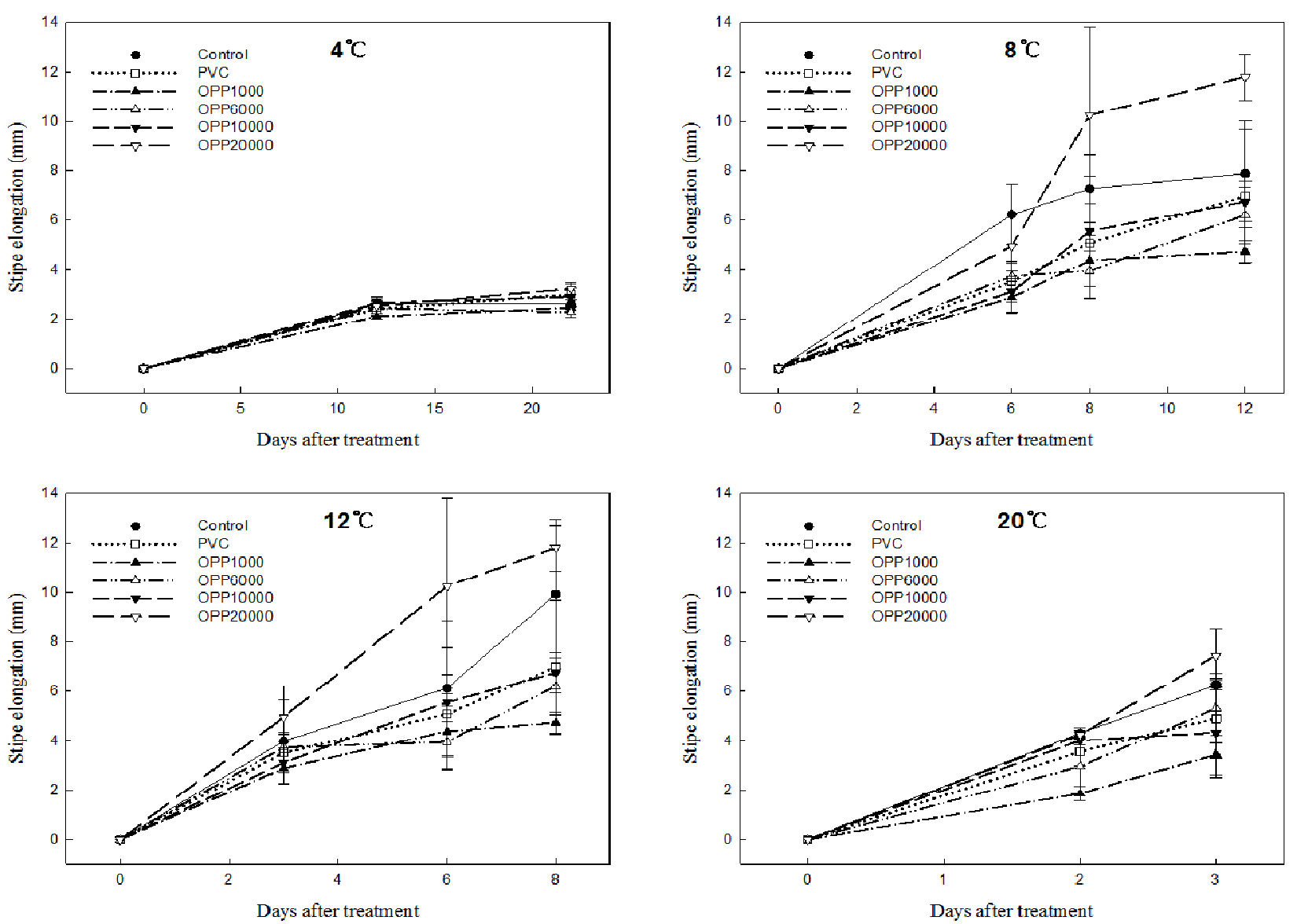

Fig. 5. Changes in stipe elongation of button mushroom with different packaging film during storage at $4,8,12,20^{\circ} \mathrm{C}$.

Values are means $\pm \mathrm{SD}(\mathrm{n}=4)$.

대 신장을 억제하는 가스 농도는 저장 온도가 높을수록 낮은 산소와 높은 이산화탄소 농도가 요구되는 것으로 판단 되었다.

\section{경 도}

양송이 조직 경도 변화는 Table 1 과 같다. 초기 양송이 갓의 경도는 $15.9 \mathrm{~N}$ 이었고 모든 온도에서 저장 기간이 경과 함에 따라 저장 후기에 경도가 전반적으로 감소한 경향이 나타났다. 처리구 간 경도를 비교하였을 때, 4 와 $20^{\circ} \mathrm{C}$ 저장 에서는 처리 간 유의적인 $(\mathrm{p}<0.05)$ 차이가 없었다. 8 과 $12^{\circ} \mathrm{C}$ 저장에서는 저장 후기에 OPP 1000 의 경도가 대조구 및 다른 필름 처리구에 비해 유의하게 높은 값을 유지하였다. $\mathrm{OPP} 1000$ 은 갓 개열과 대 신장이 처리구 중 가장 낮은 값을 나타내었는데 이러한 조직 생장의 억제가 저장 후기의 높은 경도 값에 반영되었을 것으로 판단된다. 이러한 결과는 Lee 등(22)의 실험에서 $10^{\circ} \mathrm{C}$ 저장 시 $\mathrm{PP}$ 필름에 포장한 양송이가 $\mathrm{PVC}$ 로 포장한 양송이에 비해 저장 8 일차부터 조직 경도가 높게 나타났고 동시에 PP 포장 양송이의 조직감(texture)과 갓 개열 관능점수가 $\mathrm{PVC}$ 에 비해 유의하게 높은 것과 유사
한 결과가 나타났다.

색 도

버섯 품질평가 지표 중 색도는 갈변과 관련이 있다. 버섯 의 갈변은 조직 노화의 결과로 세포막이 붕괴되어 구획화 (compartmentalization) 특성을 잃고 효소와 기질이 서로 반 응하며 갈변이 가속화된다(28). 온도 및 필름종류에 따른 양송이 외부와 내부의 색도 측정 결과는 Table 2 와 Table 3 에 각각 나타내었다. 표면의 명도 값 $\left(\mathrm{L}^{\star}\right)$ 을 측정한 결과 초기 90.0 에서 저장 기간이 경과함에 따라 값이 유의하게 감소하여 저장 후기에 72.2-88.6의 분포로 나타났다. 처리 구별로 비교했을 때, 모든 온도에서 $\mathrm{PVC}$ 가 저장 후기에 83.0-88.6의 분포를 보이며 전반적으로 높은 명도 값을 유지 하였고 OPP 필름은 그에 비해 유의하게 낮은 값을 나타냈 다. OPP 필름 중에서는 산소투과도가 높을수록 명도 값이 감소하였고 모든 온도에서 같은 경향이었다. 표면의 황청 도 값( $\left(\mathrm{b}^{\star}\right)$ 은 초기 9.7 에서 저장 기간이 경과함에 따라 유의 하게 증가하여 저장 후기에 12.7-24.6의 분포로 나타났다. 황청도 값을 처리구 별로 비교했을 때 명도 값과 반대의 
Table 1. Changes in firmness $(N)$ of button mushroom with different packaging film during storage at $4,8,12,20^{\circ} \mathrm{C}$

\begin{tabular}{|c|c|c|c|c|c|c|}
\hline $\begin{array}{l}\text { Temp. } \\
\left({ }^{\circ} \mathrm{C}\right)\end{array}$ & Treatment & & & lays of storage & & \\
\hline \multirow{7}{*}{4} & & 0 & 12 & 22 & & \\
\hline & Control & $15.9 \pm 3.6^{1 \mathrm{~A} 2)}$ & $15.4 \pm 3.8^{\mathrm{Aa} 3)}$ & $10.7 \pm 4.1^{\mathrm{Ba}}$ & & \\
\hline & PVC & $15.9 \pm 3.6^{\mathrm{A}}$ & $14.5 \pm 3.9^{\mathrm{Aa}}$ & $12.4 \pm 3.5^{\mathrm{Aa}}$ & & \\
\hline & OPP1000 & $15.9 \pm 3.6^{\mathrm{A}}$ & $17.1 \pm 6.6^{\mathrm{Aa}}$ & $8.8 \pm 4.7^{\mathrm{Ba}}$ & & \\
\hline & OPP6000 & $15.9 \pm 3.6^{\mathrm{A}}$ & $15.9 \pm 6.5^{\mathrm{Aa}}$ & $13.1 \pm 4.7^{\mathrm{Aa}}$ & & \\
\hline & OPP 10000 & $15.9 \pm 3.6^{\mathrm{A}}$ & $15.4 \pm 3.4^{\mathrm{Aa}}$ & $11.0 \pm 3.7^{\mathrm{Ba}}$ & & \\
\hline & OPP20000 & $15.9 \pm 3.6^{\mathrm{A}}$ & $14.7 \pm 4.6^{\mathrm{Aa}}$ & $10.2 \pm 3.2^{\mathrm{Ba}}$ & & \\
\hline \multirow{7}{*}{8} & & 0 & 3 & 6 & 8 & 12 \\
\hline & Control & $15.9 \pm 3.6^{\mathrm{A}}$ & $16.0 \pm 5.9^{\mathrm{Aab}}$ & $13.6 \pm 5.6^{\mathrm{Aa}}$ & $11.9 \pm 4.4^{\mathrm{Aa}}$ & $6.6 \pm 2.3^{\mathrm{Bb}}$ \\
\hline & PVC & $15.9 \pm 3.6^{\mathrm{A}}$ & $13.7 \pm 5.9^{\mathrm{ABb}}$ & $14.2 \pm 4.2^{\mathrm{ABa}}$ & $11.4 \pm 3.5^{\mathrm{ABa}}$ & $9.4 \pm 3.8^{\mathrm{Bab}}$ \\
\hline & OPP1000 & $15.9 \pm 3.6^{\mathrm{AB}}$ & $20.0 \pm 1.4^{\mathrm{Aa}}$ & $13.3 \pm 2.2^{\mathrm{BCa}}$ & $13.8 \pm 5.8^{\mathrm{BCa}}$ & $11.1 \pm 4.3^{\mathrm{Ca}}$ \\
\hline & OPP6000 & $15.9 \pm 3.6^{\mathrm{A}}$ & $16.0 \pm 5.7^{\mathrm{Aab}}$ & $17.2 \pm 4.0^{\mathrm{Aa}}$ & $14.0 \pm 4.5^{\mathrm{ABa}}$ & $7.6 \pm 2.2^{\mathrm{Bb}}$ \\
\hline & OPP 10000 & $15.9 \pm 3.6^{\mathrm{A}}$ & $14.8 \pm 4.9^{\mathrm{ABb}}$ & $13.3 \pm 5.9^{\mathrm{ABa}}$ & $10.4 \pm 3.8^{\mathrm{BCa}}$ & $7.0 \pm 2.3^{\mathrm{Cb}}$ \\
\hline & OPP20000 & $15.9 \pm 3.6^{\mathrm{A}}$ & $15.2 \pm 3.8^{\mathrm{Ab}}$ & $13.2 \pm 2.3^{\mathrm{Aa}}$ & $11.8 \pm 5.2^{\mathrm{Aa}}$ & $6.4 \pm 2.3^{\mathrm{Bb}}$ \\
\hline \multirow{7}{*}{12} & & 0 & 3 & 6 & 8 & \\
\hline & Control & $15.9 \pm 3.6^{\mathrm{A}}$ & $17.2 \pm 4.0^{\mathrm{Aa}}$ & $11.5 \pm 5.0^{\mathrm{Ba}}$ & $8.2 \pm 2.3^{\mathrm{Bab}}$ & \\
\hline & PVC & $15.9 \pm 3.6^{\mathrm{A}}$ & $16.8 \pm 2.6^{\mathrm{Aa}}$ & $13.9 \pm 5.1^{\mathrm{Aa}}$ & $9.6 \pm 3.1^{\mathrm{Bab}}$ & \\
\hline & OPP1000 & $15.9 \pm 3.6^{\mathrm{A}}$ & $16.2 \pm 4.7^{\mathrm{Aa}}$ & $10.9 \pm 3.8^{\mathrm{Ba}}$ & $11.1 \pm 4.2^{\mathrm{Ba}}$ & \\
\hline & OPP6000 & $15.9 \pm 3.6^{\mathrm{A}}$ & $13.6 \pm 4.5^{\mathrm{Aa}}$ & $11.4 \pm 5.0^{\mathrm{ABa}}$ & $7.8 \pm 2.8^{\mathrm{Bab}}$ & \\
\hline & OPP 10000 & $15.9 \pm 3.6^{\mathrm{A}}$ & $16.0 \pm 4.8^{\mathrm{Aa}}$ & $9.6 \pm 5.0^{\mathrm{Ba}}$ & $9.0 \pm 3.8^{\mathrm{Bab}}$ & \\
\hline & OPP20000 & $15.9 \pm 3.6^{\mathrm{A}}$ & $16.0 \pm 6.3^{\mathrm{Aa}}$ & $10.3 \pm 5.5^{\mathrm{Ba}}$ & $7.1 \pm 3.2^{\mathrm{Bb}}$ & \\
\hline \multirow{7}{*}{20} & & 0 & 2 & 3 & & \\
\hline & Control & $15.9 \pm 3.6^{\mathrm{A}}$ & $13.9 \pm 5.0^{\mathrm{Aa}}$ & $12.6 \pm 4.2^{\mathrm{Aa}}$ & & \\
\hline & PVC & $15.9 \pm 3.6^{\mathrm{A}}$ & $16.3 \pm 5.8^{\mathrm{Aa}}$ & $14.9 \pm 5.3^{\mathrm{Aa}}$ & & \\
\hline & OPP1000 & $15.9 \pm 3.6^{\mathrm{A}}$ & $16.1 \pm 4.4^{\mathrm{Aa}}$ & $14.7 \pm 5.0^{\mathrm{Aa}}$ & & \\
\hline & OPP6000 & $15.9 \pm 3.6^{\mathrm{A}}$ & $18.3 \pm 5.4^{\mathrm{Aa}}$ & $10.3 \pm 5.2^{\mathrm{Ba}}$ & & \\
\hline & OPP 10000 & $15.9 \pm 3.6^{\mathrm{A}}$ & $15.0 \pm 3.9^{\mathrm{ABa}}$ & $11.5 \pm 3.1^{\mathrm{Ba}}$ & & \\
\hline & OPP20000 & $15.9 \pm 3.6^{\mathrm{A}}$ & $16.9 \pm 4.6^{\mathrm{Aa}}$ & $10.9 \pm 4.3^{\mathrm{Ba}}$ & & \\
\hline
\end{tabular}

${ }^{1)}$ Each value represents the means $\pm S D(n=8)$.

2)A-C Means with different alphabets are significantly $(\mathrm{p}<0.05)$ different between each treatment for a particular storage time.

${ }^{3) a-b}$ Means with different alphabets are significantly $(\mathrm{p}<0.05)$ different within each treatment.

경향으로 나타났다. 즉 $\mathrm{PVC}$ 의 $\mathrm{b}$ * 값이 저장 후기에 가장 낮았고 OPP 필름이 높았으며, 그 중 산소투과도가 높은 필름일수록 $\mathrm{b}^{*}$ 값이 유의하게 높은 경향이었다. Lopez-Briones 등(23)은 $\mathrm{CO}_{2}$ 농도 $5 \%$ 까지는 버섯의 성숙, 갈변, 경도감소를 지연시키지만 $5 \%$ 이상에서는 갓의 내외 부 색도(yellowing)를 증가시킨다고 하였고 Lopez-Briones 등(29)은 OTR $7200 \mathrm{~mL} / \mathrm{m}^{2} / \mathrm{day} / \mathrm{atm}$ 보다 낮은 투과성을 가 진 필름에서 버섯의 성숙과 갓 개열을 지연시켰으나 내외부 갈변을 촉진하였다고 보고된 바 있다. 본 실험에서 외부 색도와 가스 환경을 분석해 보았을 때 대조구보다 필름 처리구에서 색도 변화가 크게 나타난 것으로 보아 가스
농도의 변화가 영향을 미쳤을 것으로 추측된다. 그러나 $\mathrm{OPP}$ 필름 내에서는 OTR이 높을수록 즉, 내부 $\mathrm{CO}_{2}$ 농도가 낮고 $\mathrm{O}_{2}$ 농도가 높을수록 $\mathrm{b}^{*}$ 값이 유의하게 높았던 점, 또한 PVC 필름은 가스 농도의 변화가 있으나 대조구와 색도 차이가 크게 없었던 점을 확인할 때 양송이의 외부 색도(yellowing)를 증가시키는 것은 이산화탄소 농도의 영 향 뿐 아니라 산소 농도 및 온·습도 등 복합적인 영향이 있을 것으로 판단된다.

양송이를 종단면으로 절단하여 내부의 색도를 측정한 결과 외부 색도와는 다른 경향이 나타났다. 내부 단면의 명도 값 $\left(\mathrm{L}^{*}\right)$ 은 초기 85.2에서 저장 기간이 경과함에 따라 
Table 2. Changes in color $\left(\mathrm{L}^{*}\right.$ and $\left.\mathrm{b}^{*}\right)$ of external part of button mushroom with different packaging film during storage at $4,8,12,20^{\circ} \mathrm{C}$

\begin{tabular}{|c|c|c|c|c|c|c|c|c|c|}
\hline \multirow{2}{*}{$\begin{array}{l}\text { Temp. } \\
\left({ }^{\circ} \mathrm{C}\right)\end{array}$} & \multirow{3}{*}{ Treatment } & \multicolumn{4}{|c|}{ Color $\left(\mathrm{L}^{*}\right)$} & \multicolumn{4}{|c|}{ Color $\left(b^{*}\right)$} \\
\hline & & \multicolumn{4}{|c|}{ Days of storage } & \multicolumn{4}{|c|}{ Days of storage } \\
\hline \multirow{7}{*}{4} & & & 0 & 12 & 22 & & 0 & 12 & 22 \\
\hline & Control & $90.0 \pm 1.8^{\left.1 / \mathrm{A}^{2}\right)}$ & & $87.8 \pm 1.2^{\mathrm{ABa} 3)}$ & $88.5 \pm 1.6^{\mathrm{Ba}}$ & $9.7 \pm 0.7^{\mathrm{B}}$ & & $14.8 \pm 1.4^{\mathrm{Aa}}$ & $14.8 \pm 2.6^{\mathrm{Ad}}$ \\
\hline & $\mathrm{PVC}$ & $90.0 \pm 1.8^{\mathrm{A}}$ & & $83.0 \pm 4.7^{\mathrm{Bbc}}$ & $83.0 \pm 1.9^{\mathrm{Bab}}$ & $9.7 \pm 0.7^{\mathrm{B}}$ & & $15.4 \pm 4.3^{\mathrm{Aa}}$ & $15.0 \pm 1.4^{\mathrm{Ad}}$ \\
\hline & OPP1000 & $90.0 \pm 1.8^{\mathrm{A}}$ & & $84.6 \pm 2.2^{\mathrm{Bbc}}$ & $79.3 \pm 1.2^{\mathrm{Cc}}$ & $9.7 \pm 0.7^{\mathrm{C}}$ & & $15.0 \pm 2.8^{\mathrm{Ba}}$ & $17.8 \pm 1.1^{\mathrm{Ac}}$ \\
\hline & OPP6000 & $90.0 \pm 1.8^{\mathrm{A}}$ & & $83.9 \pm 2.8^{\mathrm{Bbc}}$ & $75.6 \pm 1.9^{\mathrm{Cd}}$ & $9.7 \pm 0.7^{\mathrm{C}}$ & & $15.6 \pm 1.3^{\mathrm{Ba}}$ & $20.2 \pm 0.7^{\mathrm{Ab}}$ \\
\hline & OPP10000 & $90.0 \pm 1.8^{\mathrm{A}}$ & & $82.2 \pm 2.4^{\mathrm{Bd}}$ & $74.1 \pm 0.9^{\mathrm{Ce}}$ & $9.7 \pm 0.7^{\mathrm{C}}$ & & $16.0 \pm 2.0^{\mathrm{Ba}}$ & $21.2 \pm 0.3^{\mathrm{Aab}}$ \\
\hline & OPP20000 & $90.0 \pm 1.8^{\mathrm{A}}$ & & $86.0 \pm 1.8^{\mathrm{Bab}}$ & $72.6 \pm 0.4^{\mathrm{Cf}}$ & $9.7 \pm 0.7^{\mathrm{C}}$ & & $14.2 \pm 1.1^{\mathrm{Ba}}$ & $21.6 \pm 0.4^{\mathrm{Aa}}$ \\
\hline \multirow{7}{*}{8} & & & 0 & 8 & 12 & & 0 & 8 & 12 \\
\hline & Control & $90.0 \pm 1.8^{\mathrm{A}}$ & & $88.7 \pm 1.4^{\mathrm{Aa}}$ & $86.8 \pm 1.1^{\mathrm{Ba}}$ & $9.7 \pm 0.7^{\mathrm{C}}$ & & $13.7 \pm 1.3^{\mathrm{Bd}}$ & $16.2 \pm 1.6^{\mathrm{Ae}}$ \\
\hline & PVC & $90.0 \pm 1.8^{\mathrm{A}}$ & & $87.0 \pm 2.0^{\mathrm{Bab}}$ & $87.3 \pm 1.0^{\mathrm{Ba}}$ & $9.7 \pm 0.7^{\mathrm{B}}$ & & $15.0 \pm 1.8^{\mathrm{Acd}}$ & $15.8 \pm 1.0^{\mathrm{Ae}}$ \\
\hline & OPP1000 & $90.0 \pm 1.8^{\mathrm{A}}$ & & $86.0 \pm 1.6^{\mathrm{Bb}}$ & $81.0 \pm 1.9^{\mathrm{Cb}}$ & $9.7 \pm 0.7^{\mathrm{C}}$ & & $14.9 \pm 1.1^{\mathrm{Bcd}}$ & $18.3 \pm 2.2^{\mathrm{Ad}}$ \\
\hline & OPP6000 & $90.0 \pm 1.8^{\mathrm{A}}$ & & $82.7 \pm 1.0^{\mathrm{Bc}}$ & $78.0 \pm 0.7^{\mathrm{Cc}}$ & $9.7 \pm 0.7^{\mathrm{C}}$ & & $16.5 \pm 0.4^{\mathrm{Bb}}$ & $21.4 \pm 1.3^{\mathrm{Ac}}$ \\
\hline & OPP10000 & $90.0 \pm 1.8^{\mathrm{A}}$ & & $81.2 \pm 0.4^{\mathrm{Bc}}$ & $77.7 \pm 1.4^{\mathrm{Cc}}$ & $9.7 \pm 0.7^{\mathrm{C}}$ & & $17.9 \pm 0.9^{\mathrm{Ba}}$ & $23.2 \pm 0.8^{\mathrm{Ab}}$ \\
\hline & OPР20000 & $90.0 \pm 1.8^{\mathrm{A}}$ & & $87.5 \pm 3.7^{\mathrm{Aab}}$ & $77.2 \pm 0.4^{\mathrm{Bc}}$ & $9.7 \pm 0.7^{\mathrm{C}}$ & & $15.5 \pm 1.9^{\mathrm{Bbc}}$ & $24.6 \pm 0.8^{\mathrm{Aa}}$ \\
\hline \multirow{7}{*}{12} & & & 0 & 6 & 8 & & 0 & 6 & 8 \\
\hline & Control & $90.0 \pm 1.8^{\mathrm{A}}$ & & $88.7 \pm 1.3^{\mathrm{Aa}}$ & $85.7 \pm 2.0^{\mathrm{Bb}}$ & $9.7 \pm 0.7^{\mathrm{B}}$ & & $13.7 \pm 2.3^{\mathrm{Ac}}$ & $15.0 \pm 1.7^{\mathrm{Ab}}$ \\
\hline & PVC & $90.0 \pm 1.8^{\mathrm{A}}$ & & $87.2 \pm 2.2^{\mathrm{Bb}}$ & $87.7 \pm 1.0^{\mathrm{Ba}}$ & $9.7 \pm 0.7^{\mathrm{B}}$ & & $15.2 \pm 1.6^{\mathrm{Ab}}$ & $14.5 \pm 0.9^{\mathrm{Ab}}$ \\
\hline & OPP1000 & $90.0 \pm 1.8^{\mathrm{A}}$ & & $84.4 \pm 0.9^{\mathrm{Bc}}$ & $86.5 \pm 1.6^{\mathrm{cb}}$ & $9.7 \pm 0.7^{\mathrm{B}}$ & & $15.5 \pm 1.1^{\mathrm{Ab}}$ & $14.5 \pm 0.9^{\mathrm{Ab}}$ \\
\hline & OPP6000 & $90.0 \pm 1.8^{\mathrm{A}}$ & & $82.4 \pm 1.9^{\mathrm{Bd}}$ & $82.6 \pm 1.5^{\mathrm{Bc}}$ & $9.7 \pm 0.7^{\mathrm{B}}$ & & $16.1 \pm 1.2^{\mathrm{Ab}}$ & $15.8 \pm 0.8^{\mathrm{Ab}}$ \\
\hline & OPP10000 & $90.0 \pm 1.8^{\mathrm{A}}$ & & $82.3 \pm 1.1^{\mathrm{Bd}}$ & $81.8 \pm 1.5^{\mathrm{Bc}}$ & $9.7 \pm 0.7^{\mathrm{C}}$ & & $16.7 \pm 0.8^{\mathrm{Bab}}$ & $18.0 \pm 1.3^{\mathrm{Aa}}$ \\
\hline & OPP20000 & $90.0 \pm 1.8^{\mathrm{A}}$ & & $81.6 \pm 1.1^{\mathrm{Bd}}$ & $81.1 \pm 1.4^{\mathrm{Bc}}$ & $9.7 \pm 0.7^{\mathrm{B}}$ & & $18.0 \pm 1.0^{\mathrm{Aa}}$ & $18.4 \pm 1.4^{\mathrm{Aa}}$ \\
\hline \multirow{7}{*}{20} & & & 0 & 2 & 3 & & 0 & 2 & 3 \\
\hline & Control & $90.0 \pm 1.8^{\mathrm{A}}$ & & $88.7 \pm 1.9^{\mathrm{Ab}}$ & $83.5 \pm 4.1^{\mathrm{Bbc}}$ & $9.7 \pm 0.7^{\mathrm{C}}$ & & $12.7 \pm 2.5^{\mathrm{Bbc}}$ & $15.1 \pm 1.6^{\mathrm{Abc}}$ \\
\hline & PVC & $90.0 \pm 1.8^{\mathrm{A}}$ & & $90.7 \pm 1.8^{\mathrm{Aa}}$ & $88.6 \pm 1.4^{\mathrm{Ba}}$ & $9.7 \pm 0.7^{\mathrm{C}}$ & & $11.2 \pm 1.6^{\mathrm{Bc}}$ & $12.7 \pm 1.4^{\mathrm{Ad}}$ \\
\hline & OPP1000 & $90.0 \pm 1.8^{\mathrm{A}}$ & & $88.6 \pm 0.9^{\mathrm{Ab}}$ & $85.3 \pm 4 . .^{\mathrm{Bb}}$ & $9.7 \pm 0.7^{\mathrm{B}}$ & & $12.9 \pm 0.4^{\mathrm{Ab}}$ & $14.1 \pm 2.1^{\mathrm{Acd}}$ \\
\hline & OPP6000 & $90.0 \pm 1.8^{\mathrm{A}}$ & & $88.2 \pm 1.0^{\mathrm{Bbc}}$ & $85.5 \pm 1.1^{\mathrm{cb}}$ & $9.7 \pm 0.7^{\mathrm{C}}$ & & $12.7 \pm 0.9^{\mathrm{Bbc}}$ & $14.0 \pm 1.2^{\mathrm{Acd}}$ \\
\hline & OPP10000 & $90.0 \pm 1.8^{\mathrm{A}}$ & & $86.7 \pm 1.5^{\mathrm{Bc}}$ & $82.3 \pm 1.5^{\mathrm{Cc}}$ & $9.7 \pm 0.7^{\mathrm{C}}$ & & $13.8 \pm 1.1^{\mathrm{Bb}}$ & $16.4 \pm 1.0^{\mathrm{Ab}}$ \\
\hline & OPP20000 & $90.0 \pm 1.8^{\mathrm{A}}$ & & $81.8 \pm 2.5^{\mathrm{Bd}}$ & $78.1 \pm 1.2^{\mathrm{Cd}}$ & $9.7 \pm 0.7^{\mathrm{B}}$ & & $17.6 \pm 1.8^{\mathrm{Aa}}$ & $18.9 \pm 0.7^{\mathrm{Aa}}$ \\
\hline
\end{tabular}

${ }^{1)}$ Each value represents the means $\pm S D(n=8)$.

2)A-C Means with different alphabets are significantly $(\mathrm{p}<0.05)$ different between each treatment for a particular storage time.

${ }^{3)-d}$ Means with different alphabets are significantly $(\mathrm{p}<0.05)$ different within each treatment.

값이 유의하게 감소하여 저장 후기에 64.4-81.6의 분포로 나타났다. 처리구별로 비교하였을 때 모든 온도에서 대조 구가 전반적으로 가장 높은 명도 값이 나타났고 OPP1000이 가장 낮은 값을 유지하였다. 그 외 필름 처리구들은 온도에 따라 대조구와 비교하여 차이가 없거나 다소 낮은 경향이었 다. 황청도 값은 명도 값과 반대 경향으로 나타나 OPP1000 의 값이 가장 높았다. 양송이 내부 색도는 외부와 마찬가지 로 대조구와 PVC 필름보다 OPP 필름 처리구의 색도 변화 가 큰 편이었으나 OTR별로 구분하였을 때는 외부 색도와 반대의 경향을 나타내었다. 즉 외부 색도는 OPP 필름 중에 서 OTR이 높을수록, 내부 색도는 OTR이 낮을수록 색 변화
가 큰 경향이었다.

버섯 내부의 외관을 관찰하였을 때 OPP1000과 OPP6000 은 버섯 중앙과 대부분이 심하게 갈변됨과 동시에 손으로 누르면 수분이 나오는 현상이 있었는데 그에 비해 대조구나 $\mathrm{PVC}$ 및 $\mathrm{OPP} 20000$ 에서는 내부 갈변 정도가 심하지 않았고 조직에서 수분이 나오는 현상도 발견되지 않았다(Fig. 6). 버섯에서 과도한 이산화탄소의 축적은 세포막 손상을 야기 하고 이로 인해 경도 감소와 효소적 갈변과 같은 생리장해 를 야기할 수 있다 $(18,19,23)$ 고 보고된 바, 본 실험에서 OPP 필름 내의 고농도 이산화탄소가 저장 후기에 버섯의 내부 조직 손상에 관여했을 것으로 추측된다. 또한 OPP 필름이 


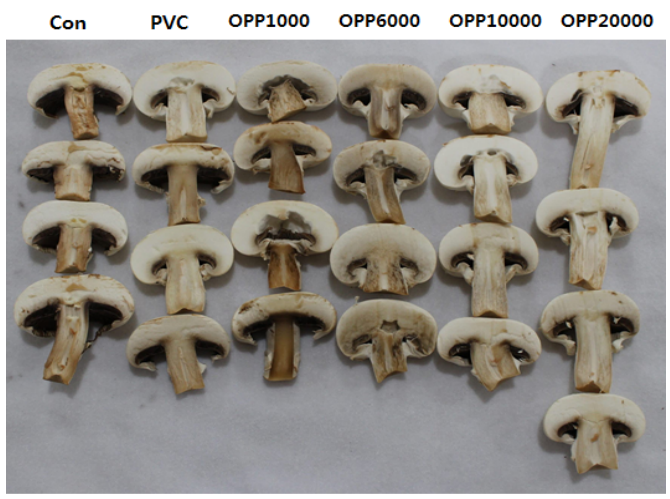

6 days at $12^{\circ} \mathrm{C}$

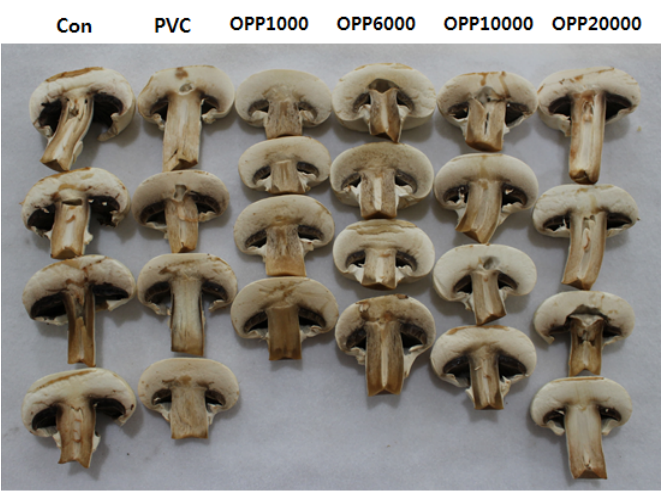

12 days at $8^{\circ} \mathrm{C}$

Fig. 6. Photographs of the internal appearance of button mushroom with different packaging film for 6 days at $12^{\circ} \mathrm{C}$ (left) and 12 days at $8^{\circ} \mathrm{C}$ (right).

Table 3. Changes in color $\left(L^{*}\right.$ and $\left.b^{*}\right)$ of internal part of button mushroom with different packaging film during storage at $4,8,12,20^{\circ} \mathrm{C}$

\begin{tabular}{|c|c|c|c|c|c|c|c|}
\hline \multirow{2}{*}{$\begin{array}{c}\text { Temp. } \\
\left({ }^{\circ} \mathrm{C}\right)\end{array}$} & \multirow{2}{*}{ Treatment } & \multicolumn{3}{|c|}{ Color $\left(\mathrm{L}^{*}\right)$} & \multicolumn{3}{|c|}{ Color $\left(b^{*}\right)$} \\
\hline & & \multicolumn{3}{|c|}{ Days of storage } & \multicolumn{3}{|c|}{ Days of storage } \\
\hline \multirow{7}{*}{4} & & 0 & 12 & 22 & 0 & 12 & 22 \\
\hline & Control & $85.2 \pm 2.0^{1) \mathrm{A} 2)}$ & $82.2 \pm 3.3^{\text {Aa3) }}$ & $68.3 \pm 3.1^{\mathrm{Ba}}$ & $11.5 \pm 0.7^{\mathrm{C}}$ & $15.3 \pm 2.2^{\mathrm{Bb}}$ & $22.0 \pm 0.7^{\mathrm{Ac}}$ \\
\hline & PVC & $85.2 \pm 2.0^{\mathrm{A}}$ & $78.0 \pm 4.2^{\mathrm{Bab}}$ & $64.0 \pm 1.6^{\mathrm{Cb}}$ & $11.5 \pm 0.7^{\mathrm{C}}$ & $16.8 \pm 1.8^{\mathrm{Bab}}$ & $24.4 \pm 0.3^{\mathrm{Aab}}$ \\
\hline & OPP1000 & $85.2 \pm 2.0^{\mathrm{A}}$ & $73.6 \pm 4.9^{\mathrm{Bb}}$ & $60.7 \pm 4.4^{\mathrm{Cc}}$ & $11.5 \pm 0.7^{\mathrm{C}}$ & $16.7 \pm 1.9^{\mathrm{Bab}}$ & $25.2 \pm 0.8^{\mathrm{Aa}}$ \\
\hline & OPP6000 & $85.2 \pm 2.0^{\mathrm{A}}$ & $70.0 \pm 3.8^{\mathrm{Bc}}$ & $64.8 \pm 1.9^{\mathrm{Cb}}$ & $11.5 \pm 0.7^{\mathrm{C}}$ & $17.7 \pm 1.2^{\mathrm{Ba}}$ & $24.0 \pm 1.6^{\mathrm{Aab}}$ \\
\hline & OPP10000 & $85.2 \pm 2.0^{\mathrm{A}}$ & $74.8 \pm 3.7^{\mathrm{Bbc}}$ & $66.5 \pm 3.6^{\mathrm{Cab}}$ & $11.5 \pm 0.7^{\mathrm{C}}$ & $17.5 \pm 1.6^{\mathrm{Ba}}$ & $22.6 \pm 0.9^{\mathrm{Abc}}$ \\
\hline & OPP20000 & $85.2 \pm 2.0^{\mathrm{A}}$ & $76.7 \pm 8.5^{\mathrm{Bb}}$ & $67.0 \pm 2.8^{\mathrm{Cab}}$ & $11.5 \pm 0.7^{\mathrm{C}}$ & $17.4 \pm 1.4^{\mathrm{Ba}}$ & $22.8 \pm 1.2^{\mathrm{Abc}}$ \\
\hline \multirow{7}{*}{8} & & 0 & 8 & 12 & 0 & 8 & 12 \\
\hline & Control & $85.2 \pm 2.0^{\mathrm{A}}$ & $85.9 \pm 2.8^{\mathrm{Aa}}$ & $79.9 \pm 8.5^{\mathrm{Bab}}$ & $11.5 \pm 0.7^{\mathrm{C}}$ & $13.6 \pm 2.4^{\mathrm{Ba}}$ & $16.4 \pm 1.8^{\mathrm{Abc}}$ \\
\hline & $\mathrm{PVC}$ & $85.2 \pm 2.0^{\mathrm{A}}$ & $82.9 \pm 5.2^{\mathrm{Aab}}$ & $80.2 \pm 7.1^{\mathrm{Aab}}$ & $11.5 \pm 0.7^{\mathrm{B}}$ & $14.3 \pm 2.8^{\mathrm{Aa}}$ & $15.8 \pm 2.3^{\mathrm{Abc}}$ \\
\hline & OPP1000 & $85.2 \pm 2.0^{\mathrm{A}}$ & $81.8 \pm 4.8^{\mathrm{Aab}}$ & $64.4 \pm 11.0^{\mathrm{Bc}}$ & $11.5 \pm 0.7^{\mathrm{B}}$ & $13.2 \pm 1.5^{\mathrm{Ba}}$ & $18.9 \pm 2.6^{\mathrm{Aa}}$ \\
\hline & OPP6000 & $85.2 \pm 2.0^{\mathrm{A}}$ & $78.1 \pm 6.3^{\mathrm{ABb}}$ & $71.1 \pm 12.8^{\mathrm{Bbc}}$ & $11.5 \pm 0.7^{\mathrm{C}}$ & $15.1 \pm 1.3^{\mathrm{Ba}}$ & $17.4 \pm 2.5^{\mathrm{Aab}}$ \\
\hline & OPP10000 & $85.2 \pm 2.0^{\mathrm{A}}$ & $79.0 \pm 6.0^{\mathrm{Bb}}$ & $73.6 \pm 4.2^{\mathrm{Cb}}$ & $11.5 \pm 0.7^{\mathrm{B}}$ & $15.1 \pm 1.7^{\mathrm{Aa}}$ & $16.2 \pm 1.1^{\mathrm{Abc}}$ \\
\hline & OPP20000 & $85.2 \pm 2.0^{\mathrm{A}}$ & $84.3 \pm 2.2^{\mathrm{Aa}}$ & $84.0 \pm 3.6^{\mathrm{Aa}}$ & $11.5 \pm 0.7^{\mathrm{B}}$ & $13.8 \pm 1.2^{\mathrm{Aa}}$ & $14.6 \pm 1.6^{\mathrm{Ac}}$ \\
\hline \multirow{7}{*}{12} & & 0 & 6 & 8 & 0 & 6 & 8 \\
\hline & Control & $85.2 \pm 2.0^{\mathrm{A}}$ & $86.9 \pm 2.9^{\mathrm{Aa}}$ & $76.9 \pm 1.1^{\mathrm{Ba}}$ & $11.5 \pm 0.7^{\mathrm{B}}$ & $10.4 \pm 2.1^{\mathrm{Bb}}$ & $14.1 \pm 0.6^{\mathrm{Ac}}$ \\
\hline & $\mathrm{PVC}$ & $85.2 \pm 2.0^{\mathrm{A}}$ & $84.0 \pm 5.4^{\mathrm{Aab}}$ & $77.2 \pm 0.7^{\mathrm{Ba}}$ & $11.5 \pm 0.7^{\mathrm{B}}$ & $10.2 \pm 0.8^{\mathrm{Bb}}$ & $14.2 \pm 0.7^{\mathrm{Ac}}$ \\
\hline & OPP1000 & $85.2 \pm 2.0^{\mathrm{A}}$ & $82.0 \pm 5.2^{\mathrm{Aab}}$ & $73.2 \pm 1.0^{\mathrm{Bb}}$ & $11.5 \pm 0.7^{\mathrm{B}}$ & $12.9 \pm 1.5^{\mathrm{Ba}}$ & $17.2 \pm 0.6^{\mathrm{Aa}}$ \\
\hline & OPP6000 & $85.2 \pm 2.0^{\mathrm{A}}$ & $78.9 \pm 6.8^{\mathrm{Bc}}$ & $71.8 \pm 2.4^{\mathrm{Cb}}$ & $11.5 \pm 0.7^{\mathrm{B}}$ & $12.6 \pm 2.1^{\mathrm{Ba}}$ & $17.5 \pm 0.8^{\mathrm{Aa}}$ \\
\hline & OPP10000 & $85.2 \pm 2.0^{\mathrm{A}}$ & $83.8 \pm 4.6^{\mathrm{Aab}}$ & $71.2 \pm 3.0^{\mathrm{Bb}}$ & $11.5 \pm 0.7^{\mathrm{B}}$ & $10.6 \pm 1.8^{\mathrm{Bb}}$ & $16.8 \pm 0.5^{\mathrm{Ab}}$ \\
\hline & OPP20000 & $85.2 \pm 2.0^{\mathrm{A}}$ & $87.8 \pm 2.9^{\mathrm{Aa}}$ & $72.5 \pm 1.9^{\mathrm{Bb}}$ & $11.5 \pm 0.7^{\mathrm{B}}$ & $10.2 \pm 1.4^{\mathrm{Bb}}$ & $16.4 \pm 0.6^{\mathrm{Ab}}$ \\
\hline \multirow{7}{*}{20} & & 0 & 2 & 3 & 0 & 2 & 3 \\
\hline & Control & $85.2 \pm 2.0^{\mathrm{A}}$ & $86.3 \pm 3.9^{\mathrm{Ab}}$ & $81.1 \pm 6.9^{\mathrm{Ba}}$ & $11.5 \pm 0.7^{\mathrm{B}}$ & $10.8 \pm 0.7^{\mathrm{Ba}}$ & $14.3 \pm 2.2^{\mathrm{Aa}}$ \\
\hline & PVC & $85.2 \pm 2.0^{\mathrm{A}}$ & $87.6 \pm 2.0^{\mathrm{Ab}}$ & $86.1 \pm 3.2^{\mathrm{Aa}}$ & $11.5 \pm 0.7^{B}$ & $9.2 \pm 1.8^{\mathrm{Cab}}$ & $14.0 \pm 2.5^{\mathrm{Aa}}$ \\
\hline & OPP1000 & $85.2 \pm 2.0^{\mathrm{A}}$ & $88.8 \pm 2.8^{\mathrm{Ab}}$ & $80.6 \pm 6.9^{\mathrm{Ba}}$ & $11.5 \pm 0.7^{\mathrm{B}}$ & $8.6 \pm 1.2^{\mathrm{Cbc}}$ & $14.8 \pm 3.0^{\mathrm{Aa}}$ \\
\hline & OPP6000 & $85.2 \pm 2.0^{\mathrm{A}}$ & $86.1 \pm 2.4^{\mathrm{Ab}}$ & $73.4 \pm 6.0^{\mathrm{Bb}}$ & $11.5 \pm 0.7^{\mathrm{B}}$ & $9.8 \pm 1.1^{\mathrm{Cab}}$ & $14.8 \pm 2.2^{\mathrm{Aa}}$ \\
\hline & OPP10000 & $85.2 \pm 2.0^{\mathrm{A}}$ & $87.9 \pm 3.0^{\mathrm{Ab}}$ & $82.4 \pm 2.5^{\mathrm{Ba}}$ & $11.5 \pm 0.7^{\mathrm{B}}$ & $9.5 \pm 1.3^{\mathrm{Cab}}$ & $14.3 \pm 2.2^{\mathrm{Aa}}$ \\
\hline & OPP20000 & $85.2 \pm 2.0^{\mathrm{A}}$ & $91.2 \pm 2.6^{\mathrm{Aa}}$ & $85.6 \pm 3.4^{\mathrm{Ba}}$ & $11.5 \pm 0.7^{\mathrm{A}}$ & $8.1 \pm 0.7^{\mathrm{Bc}}$ & $12.2 \pm 3.2^{\mathrm{Aa}}$ \\
\hline
\end{tabular}

${ }^{1)}$ Each value represents the means $\pm \mathrm{SD}(\mathrm{n}=8)$.

2)A-C Means with different alphabets are significantly $(\mathrm{p}<0.05)$ different between each treatment for a particular storage time.

${ }^{3)-c}$ Means with different alphabets are significantly $(\mathrm{p}<0.05)$ different within each treatment. 
투습도가 낮아 필름 내부의 습도와 수증기압이 높았을 것으 로 생각되는데 이러한 환경이 조직 손상과 더불어 수침 현상과 같은 장해를 야기했을 것으로 판단된다.

본 실험을 종합하여 볼 때, 양송이의 품질을 유지하기 위한 최적 $\mathrm{MA}$ 포장 조건은 필름의 산소투과도가 낮아 갓 개열 억제 및 조직감을 유지하고, 이산화탄소 및 수분투과 도가 다소 높아 고농도 이산화탄소와 높은 수증기압에 의한 내부 갈변 및 조직감 변성과 같은 장해를 완화할 수 있어야 한다. 본 실험에 사용된 필름 중 PVC는 산소투과도가 OPP $1,000-6,000 \mathrm{~mL} / \mathrm{m}^{2} / \mathrm{day} / \mathrm{atm}$ 와 유사하고 이산화탄소 투과도 는 OPP $20,000 \mathrm{~mL} / \mathrm{m}^{2} / \mathrm{day} / \mathrm{atm}$ 와 유사하며 수분투과도는 $\mathrm{OPP}$ 필름보다 높은 수준이었으며 전반적인 품질 요소 즉 갓 개열, 대 신장, 내외부 갈변에서 대조구나 OPP 필름의 양송이에 비해 품질 변화가 적었다.

\section{요 약}

양송이 유통에 적합한 필름 포장방법 연구를 위해 저장 온도 및 필름 산소투과도에 따른 양송이 품질변화를 분석하 였다. 실험에 이용된 필름은 PVC와 OPP(OTR $1,000,6,000$, $10,000,20,000 \mathrm{~mL} / \mathrm{m}^{2} / \mathrm{day} / \mathrm{atm}$ )이고 저장 온도는 $4,8,12$, $20^{\circ} \mathrm{C}$ 로 설정하였다. 분석 결과, 중량감소율은 대조구, PVC, $\mathrm{OPP}$ 순으로 높았다. 갓 개열은 온도 별로 결과가 다르게 나타나 $8^{\circ} \mathrm{C}$ 이상에서 필름 처리구의 갓 개열 억제 효과가 나타났고 $12^{\circ} \mathrm{C}$ 에서는 필름 내부의 산소 농도가 낮을수록 억제 효과가 높은 경향이었다. 필름 중 $\mathrm{OPP} 20000$ 은 $20^{\circ} \mathrm{C}$ 에 서 갓 개열 억제 효과가 나타나지 않았다. 대 신장은 모든 온도에서 전반적으로 필름 처리구가 대조구에 비해 억제되 었으나 예외적으로 OPP20000은 대 신장이 대조구보다 오 히려 촉진되는 결과였다. 조직의 경도는 필름 중 OPP1000 이 다른 처리구에 비해 유의하게 높았다. 버섯의 내외부 색도는 모두 OPP 필름의 버섯이 대조구와 $\mathrm{PVC}$ 에 비해 색 변화가 큰 경향이었다. 전반적으로 $\mathrm{OPP}$ 는 중량감소, 갓 개열, 대 신장, 조직 경도에서 대조구에 비해 품질이 유지되는 효과가 있었으나 온도 및 산소투과도에 따라 효과 의 차이가 있었고 OPP20000은 조직 생장 억제와 관련된 효과가 나타나지 않았다. OPP1000과 OPP6000은 OPP 중 조직 생장 억제에 가장 효과적이었으나 내부 단면에서 조직 손상 및 수침 현상과 같은 장해가 나타났다. 한편 $\mathrm{PVC}$ 필름 은 중량감소, 갓 개열, 대 신장이 대조구에 비해 변화가 적었고 내외부 갈변은 $\mathrm{OPP}$ 보다 변화가 적어 전반적인 품질 변화가 적은 것으로 분석되었다.

\section{감사의 글}

이 연구는 농촌진흥청 연구사업(과제번호: PJ01200602)
의 지원에 의해 수행되었습니다.

\section{References}

1. Park SS, Lee KD, Min TJ (1995) Study on the screening development of antibiotics in the mushrooms. Korean $\mathrm{J}$ Mycol, 23, 176-189

2. Chang MS, Lee DU, Cho SD, Jhune CS, Kim GH (2012) Survey on packaging status and effects of precooling on the quality of Agaricus bisporus. Korean J Food Preserv, 19, 67-73

3. Kader AA (1985) Postharvest biology and technology an overview. In: Postharvest technology of horticultural crops, The reagent of the University of California, Division of agricultural and nutritional resource, Richmond, CA, USA, p 3-8

4. Warwick MG, Tsuneda A (1997) The interaction of the soft rot bacterium Pseudomonas gladroli pv. agaricia with Japanese cultivated mushroom. Can J Micobiol, 43, 639-648

5. Lee JS (1999) Effects of modified atmosphere packaging on the quality of chitosan and $\mathrm{CaCl}_{2}$ coated mushroom (Agaricus bisporus). Korean J Food Sci Technol, 31, 1308-1314

6. Kim BS, Park SY, Chang MS, Kwon AS (2007) Effect of prolongation by precooling treatment and improved packing of mushrooms (Agaricus bisporus). Korean $\mathrm{J}$ Food Preserv, 14, 109-112

7. Kim BS (1994) Development of precooling system and its related technology for fruits and vegetables. Korea Food Institute, E1291-0530, p 267

8. Yuanyuan L, Jie Z, Xiaotuo W, Qiong L, Wei L, Xinfang X, Zhidong W, Wenqiamg G (2016) Effects of UV-C irradiation on the physiological and antioxidant responses of button mushrooms (Agaricus bisporus) during storage. Int J Food Sci Technol, 51, 1502-1508

9. Hershko V, Nussinovitch A (1998) Relationships between hydrocolloid coating and mushroom structure. J Agric Food Chem, 46, 2988-2997

10. Khatereh NA, Pejman M, Mojhgan FS (2013) Use of soluble Methyl jasmonate on increase of lifetime after harvesting mushroom (Agaricus bisporus). Int Res J Appl Basic Sci, 6, 424-427

11. Ku KJ, Ma YH, Shin HY, Lee SH, Park JH, Kim LH, Song KB (2006) Effects of chlorine dioxide treatment on quality and microbial change of Agaricus bisporus 
Sing during storage. J Korean Soc Food Sci Nutr, 35, 955-959

12. Roy S, Anantheswaran RC, Beelman RB (1995) Fresh mushroom quality as affected by modified atmosphere packaging. Food Sci, 60, 334-340

13. Kim JH, Kim JK, Moon KD, Sohn TH, Choi JU (1995) Effect of MAP and CA storage on quality mushrooms (Agaricus bisporus) during storage. Korean J Postharvest Sci Technol Agric Prod, 2, 225-232

14. Taghizadeh M, Gowen A, Ward P, O'Donnell CP (2010) Use of hyperspectral imaging for evaluation of the shelf-life of fresh white button mushrooms (Agaricus bisporus) stored in different packaging films. Innovative Food Sci Emerging Technol, 11, 423-431

15. Kader AA (1986) Biochemical and physiological basis for effects of controlled and modified atmospheres on fruits and vegetables. Food Technol, 40, 99-104

16. Saltveit ME Jr (1997) A summary of CA and MA requirements and recommendations for harvested vegetables. In: Saltveit ME (Editor) Proceedings of the $7^{\text {th }}$ International Controlled Atmosphere Reserach Conference, Davis, CA, USA, p 98-117

17. Farber JN, Harris LJ, Parish ME, Beuchat LR, Suslow TV, Gorney JR, Garrett EH, Busta FF (2003) Microbiological safety of controlled and modified atmosphere packaging of fresh and fresh-cut produce. Compr Rev Food Sci Food Saf, 2, 142-160

18. Burton KS, Frost CE, Nichols R (1987) A combination of plastic permeable film system for controlling post-harvest mushroom quality. Biotechnol Lett, 9, 529-534

19. Varoquaux P, Gouble B, Barron C, Yildiz F (1999) Respiratiory parameters and sugar catabolism of mushroom (Agaricus bisporus Lange). Postharvest Biol Technol, 16, 51-61
20. Ares G, Lareo C, Lema P (2007) Modified atmosphere packaging for postharvest storage of mushrooms: a review. Fresh Produce, 1, 32-40

21. Singer R (1986) The Agaricales in modern taxonomy. $4^{\text {th }}$ ed, Koeltz Scientific Books, Koeningstein, Germany, p 981

22. Lee DU, Chang MS, Cho SD, Jhune CS, Kim GH (2013) Quality changes in mushrooms (Agaricus bisporus) due to their packaging materials during their storage. Korean J Food Preserv, 20, 7-13

23. Lopez-Briones G, Varoquaux P, Chambroy Y, Bouquant J, Bureau G, Pascat B (1992) Storage of common mushroom under controlled atmospheres. Int J Food Sci Technol, 27, 493-505

24. Braaksma A, Schaap DJ, de Vrije T, Jongen WMF, Woltering EJ (1994) Ageing of mushroom (Agaricus bisporus) under post-harvest conditions. Postharvest Biol Technol, 4, 99-110

25. Sveine E, Klougart A, Rasmussen CR (1967) Ways of prolonging the shelf-life of fresh mushrooms. Mushroom Sci, 6, 463-474

26. Murr DP, Morris LL (1974) Influence of $\mathrm{O}_{2}$ and $\mathrm{CO}_{2}$ on O-diphenol oxidase activity in mushrooms. J Am Soc Hortic Sci, 99, 155-158

27. Nichols R, Hammond JBW (1973) Storage of mushrooms in pre-packs: the effect of changes in carbon dioxide and oxygen on quality. J Sci Food Agric, 24, 1371-1381

28. Jolivet S, Arpin N, Wichers HJ, Pellon G (1998) Agaricus bisporus browning: a reviw. Mycol Res, 102, 1459-1483

29. Lopez-Briones G, Varoquaux P, Bureau G, Pascat B (1993) Modified atmosphere packaging of common mushroom. Int J Food Sci Technol, 28, 57-68 